DOI: $10.1515 /$ hssr -2017-0026

HSS VI.3 (2017)

\title{
"We Have Poetry / So We Do Nor Die of History" On the Interplay Between Poetry, Science, and Ideology
}

\author{
Ikram Hili *
}

University of Monastir, Tunisia

\begin{abstract}
Important as they are in people's mental and intellectual development and in their appreciation of the things around them, the Humanities remain a field that is, more often than not, frowned upon among people who firmly believe that the STEM fields are much more important, practical, and lucrative in a rapidly growing and competitive workplace. Besides, when scientific and technological breakthroughs have invaded every nook and cranny of our lives, the incessant comparison between science and the arts does not, and actually should not strike us as new or even shocking. The present paper seeks to revisit the status of the Humanities nowadays, by shedding light on the crisis befalling this field (inter)nationally. The paper also aims at providing a reappraisal of the moment of poetry-one that substantiates Poet Meena Alexander's famous line, "We have poetry / So we do not die of history." This is achieved through readings of Sylvia Plath's so-called hospital poems that highlight the deft interplay between poetry, science and ideology.
\end{abstract}

Keywords:

humanities, STEM fields, poetry, science, ideology, history, S. Plath.

\section{1. "The Silent Crisis": An Overview of the Status of the Humanities both in the United States and Tunisia}

Ask a Tunisian parent to envision a career in the Humanities for their children, and stand back. Certainly, this attitude should not be taken as a

\footnotetext{
* Higher Institute of Applied Languages of Moknine, University of Monastir, Avenue des Martyrs - Moknine - 5050; ikram_hili@hotmail.com
} 
rule of thumb; still, it is shared among many parents nowadays, not only in Tunisia, but also in other developed countries such as the United States. In her seminal book Not for Profit: Why Democracy Needs the Humanities, Martha C. Nussbaum describes the crisis overtaking the Humanities all over the world as "the silent crisis": "a crisis that goes largely unnoticed, like a cancer; a crisis that is likely to be, in the long run, far more damaging to the future of democratic self-government: a worldwide crisis in education" (Nussbaum, 2010: 1-2). Nussbaum's worries about the status of the Humanitiesresonate with current concerns, when the National Humanities Alliance (NHA) posted, on 19 January 2017, reported that "the Trump Administration is considering a budget blueprint that would call for the elimination of the National Endowment for the Humanities (NEH)."

In this case, the disparagement of a career in the Humanities seems premised on the presumption that it is not asremunerative as a career in business. Barack Obama, on the other hand, seemed to share a similar view when, in one of his speeches on education, he implicitly referred to the Humanities as "things that don't matter" (qtd. in Nussbaum, 2010: 138). In fact, commending the educational system in the Far East, Singapore in particular, he said, verbatim: "They are spending less time teaching things that don't matter, and more time teaching things that do. They are preparing their students not only for high school or college, but for a career. We are not" (qtd. in Nussbaum, 2010: 138).

Even more compelling, in this regard, is Nussbaum's comment on Obama's statement when she assumes that, according to him and to many others, "'things that matter' is taken to be equivalent to 'things that prepare for a career" (Nussbaum, 2010: 138). For this reason and many more, on which I shall dwell later with more details, it is "fine for them [the Humanities] to be downsized, and for some departments to be eliminated completely" (Nussbaum, 2010: 123). As the Modern Language Association reported in 2004, "When an increasingly shrinking pie is being divvied up, it's the humanities that gets the crumbs" (qtd. in Aldama, 2008: 265).

Tunisians, it seems, are moving in a similar direction, that is, devaluing the Humanities and encouraging the cultivation of what they perceive as commendably technical and practical knowledge. Very often, we see some parents proud when their children enter medical or engineer schools, but skeptical, if not ashamed, when their children elect to pursue a graduate 
degree in literature, philosophy, arts, etc. Putting himself in the shoes of these parents and students who share similar views, Luis Aldama, a Professor of literature, asksthe following questions on their behalf, voicing their doubts and reservations about the Humanities:

Why become a professor - especially of literature? Why devote years and years of study to a profession that, in the best of cases, will land you a job somewhere you least expect (with little pay) and that seemingly has little consequence on the progressive shaping of an already decrepit reality? (Aldama, 2008: 106)

Although Aldama talked within a strictly American context, I believe that these questions reflect concerns very comparable to those that Tunisian parents and students harbor when they are asked to gauge a teaching career in the Humanities. Such view is what makes the Humanities, more than ever before, a field "both precious and profoundly endangered," as Nussbaum rightly observes (Nussbaum, 2010: 8).

\section{The Humanities Nowadays: A Repelling Magnet}

\section{Poor Unemployment Prospects for the Humanities}

In a world plagued by cutthroat competition and the inordinate pursuit of profitable opportunities, students grow more and more concerned with the equivalent economic payoff of their diplomas, which we should acknowledge without demur. Accordingly, many students believe that the skills they need to develop so as to snatch a job from the jaws of today's fierce competitions, so to speak, are summarily found in business and engineer schools. Encapsulating some people's views about the Humanities when it comes to the job market, Paul Jay holds that:

One model sees the humanities as a rarefied refuge from the world of practical concerns and vocational goals, while the other sees the humanities as openly hostile to the utilitarian values of the world of business, a place in which to develop concrete opposition to those values. (Jay, 2014: 146)

Here, Jay talks about "the managerial values of higher education [that are] becoming increasingly corporate" - a situation even more intensified 
especially after the economic recession of 2008 in the United States, which affected, in its turn, global economy (Jay, 2014: 18).

\section{The Humanities and Today's Technological and Instrumental Age}

"Over the past century," John Paul Russo wrote in The Future without a Past, "the technological system has gradually become so intrinsic and allpervasive that, like the air we breathe or the purloined letter, it often seems invisible" (Russo, 2005: 23). Indeed, in an era of technological overkill, it is conspicuous that the Humanities, or maybe people's interest in them, have become threatened by a crazy flurry of technological advances that, so the argument goes, attests to the impracticality of the Humanities. What is more, some students perceive this field as "backward looking and without any utility in an age of exploding technology," Jay observes. "For this reason," he adds, "students are flocking to the science, technology, engineering, and mathematics (STEM) disciplines because, unlike the humanities, they are forward looking" (Jay 2014: 7).

Besides, some students go so far as to argue that success in these fields, i.e. STEM, is within one's easy reach if one has the necessary analytical skills and so on (I heard some student arguing in favor of STEM disciplines, saying: "it is as easy and manageable as one plus one simply equals two"), unlike the Humanities - a field which they find shrouded in ambiguity, incurring much uncertainty about, say, their school results. In this regard, I find Russo's comment on students' concern with "passing" instead of "learning" (and passing, I add) so intriguing that I am quoting it in full:

Technology has somewhat decimated the humanities. Education is rich in the training of techniques and poor in the development of the self, of inwardness, Innigkeit, the emphasis falls on passing, not on learning. What too frequently results is an individual captivated by fads and technological gadgets, blunted in perception, and abandoned to the mercies of the media and other organs of culture. At the same time I contend that the humanities in many instances have withstood the worst aspects of technologization, and can continue to do so. (Russo, 2005: 18)

These aspects of "technologization," as Russo calls them, are not the only challenges that the Humanities have to live up to nowadays. In what 
follows, I shall dwell on yet another reason behind students' shying away from the Humanities, particularly from literature.

\section{Literature as a La-La Land for Some Students}

Although presented under a separate heading, this section cannot be severed from the previous reasons that I discussed earlier; it rather confirms them. Some students find literature difficult because there is a real language problem, mainly for non-native speakers of English. Linking this to the nefarious impact of technology on students nowadays, Russo provides the example of video game language, holding that computer language is sweeping away literary language. He writes:

The average video game does not have much language, and what little there is hardly varies from box-top direction.... One should not wonder at students' turning away from complex language, which requires much more effort to decode and which must often seem utterly opaque compared to the luster of an image. (Russo, 2005: 36)

Strikingly, Russo asserts, "within my own teaching career I have observed the English of Shakespeare becoming a foreign language to my students" (Russo, 2005: 36). Having taught literature myself, I would not go further down as to talk about Shakespeare's language because even Beckett's language seems, at times, foreign to some students (albeit symbolically reflecting post-modern language crisis). I would simply say that I sometimes find myself caught between a rock and a hard place, so to speak. Some English majors' mistakes in a writing assignment are excruciatingly painful so much so that I might risk be laboring the obvious if I enumerate them.

\section{The Humanities Matter Still}

Are the humanities important because they constitute a body of knowledge to be preserved, or because they foster a valuable set of skills? (Jay, 2014: 21)

Pondering Jay's questions on the value of the Humanities, I would say that they fulfill both roles: the cultivation of essential skills and the 
preservation of cultural and historical heritage. To debunk the economic argument against the utility of the Humanities, Harvard President Drew Faust avers, in a ringing remark: "Human beings need meaning, understanding, and perspective as well as jobs. The question should not be whether we can afford to believe in such purposes in these times, but whether we can afford not to" (qtd. in Nussbaum, 2010:124).

At the level ofthe individual, the Humanities help foster our faculties of thought and nurture our imagination, whichhelps us fathom outwhat it means to be human, what it means to build human relationships based on empathy, tolerance and mutual understanding. Observing a painting or reading a poem are deep human endeavors because they encourage rigorous, critical reading, and even make us develop skepticism about the things that we tend to take for granted. Dissecting a work of art sometimes means digging out the ideological overtones inherent in it so as tobetter understand the intricacies of a particular time period. As Jay puts it,

What could be more important than developing an ability to track how history, philosophy, literature, and art represent the world of human experience in ways that reflect, perpetuate, or critique uneven forms of power related to gender, sexuality, class, and race? (Jay, 2014: 4)

At the level of society, the Humanities help us "approach world problems as a "citizen of the world" and endow us with the "ability to imagine sympathetically the predicament of another person," Nussbaum explains (Nussbaum, 2010: 7). We need empathy in a world that can hardly pull its parts together. That is why the Humanities help us approach complex life issues, life stories "in a way informed by an understanding of a wide range of human stories, not just by aggregate data" (Nussbaum, 2010: 26).

Given all these assets, dismissing the Humanities could not be beyond reproach. Nussbaum goes so far as to aver that if we continue to perceive them as little short of "useless frills,"then "the future of the world's democracies hangs in the balance" (Nussbaum, 2010: 2). And the result will be giving rise to a generation of robots and money-maniacs. Worse still, we would end up with "Nations of technically trained people who do not know how to criticize authority, useful profit-makers with obtuse 
imaginations ... a suicide of the soul ${ }^{1}$ " (Nussbaum, 2010: 142). True, the Humanities do not prompt scientific discoveries, in the strict sense of the phrase, nor do they bring about technological breakthroughs, but they do help us produce "insight, analysis, logic, speculation, historical knowledge, linguistic mastery, geographic precision, aesthetic production, and complex religious understanding" - faculties that we need in science as well (Aldama, 2008: 266).

\section{The Humanities and Science: A Story of Antagonistic Harmony}

Thus far, I have been arguing in favor of the Humanities, drawing upon insights of scholars who are alive to the crisis befalling this field. Far from downplaying the role of science or aiming at creating rivalry between STEM disciplines and the Humanities, I mean to argue that the seemingly sharp divide between them can be ironed out if we give each its due importance, appreciating their equal import.

Science and poetry, for instance, provide us with metaphors to understand the intricacies of life. Accordingly, a scientist and a poet, have much in common than what is commonly acknowledged among people. As Ruth Padel puts it, "A new metaphor is a new mapping of the world" (Padel, 2014: Web). And metaphors tickle our imagination - one that we need "[to press] back against the pressure of reality" because "the expression of it, the sound of its words, helps us to live our lives," as Wallace Stevens eloquently puts it (Stevens, 1960: 36). What is more, Padel talks about "parental" relationship between poetry and science that dates back to the sixth and fifth centuries BC. Back then, scientific discoveries and theories were, in fact, outlined in verse.

It follows, then, that science and the Humanities in general can fuse together, conceiving, as a result, innovative domains such as Digital Humanities, which is based primarily on the incorporation of technology while teaching/studying the Humanities. In this regard, Jayprovides many examples of what he calls "engaged humanities:" emerging fields such as Humanities+ programs at several U.S. Colleges, Public Humanities, Field Philosophy and the enticing field of Narrative Medicine ${ }^{2}$. For the scope of this paper, focus falls upon Narrative Medicine, which paves the way for the analysis of Sylvia Plath's so-called hospital poems, and which further substantiates the symbiotic relationship between poetry and science. 
In this regard, Dr. Rita Charon firmly believes that "the effective practice of medicine requires narrative competence, that is, the ability to acknowledge, absorb, interpret, and act on the stories and plights of others" (qtd.in Jay, 2014: 151). Narrative medicine acknowledges that practicing medicine is, after all, practicing an art - the art of listening to other people's narrative of illness and stories of their suffering. Many poems shed light, aesthetically, on these plights. Sylvia Plath's "Three Women," as well as her other hospital poems are good illustrations of the interplay between poetry and scientific practice, poetry and the ideological machinery of the Plath's era, given that Plath presents the hospital as an ideological apparatus, in the Althusserian sense.

\section{Science and Ideology in Sylvia Plath's Hospital Poems:}

I, too, dislike it: there are things that are important beyond all this fiddle. Reading it, however, with a perfect contempt for it, one discovers in it after all, a place for the genuine.

(Marianne Moore, "Poetry")

To some readers and critics who keep on reading Plath's works while falling back onher life and her tragic death, her poetry still plays second fiddle to "pure" poetry, however defined. In fact, a huge amount of critical reception of Plath's oeuvre confines it to biographical readings or to the Confessional mode of poetry - being an egregious disclosure of personal matters and domestic failures. But even when clustered within Confessional poetry, one should make allowances for the social, cultural and even political chords that the Confessionals evoked in their poems, sometimes bluntly, at other times still, in a very subtle way. As Marianne Moore puts it, there is in "it after all, a place for the genuine" ("Poetry").

In this connection, far from uprooting us from reality, reading poetry makes us all the more moored to it. The process becomes akin to an archeological work done on the site of the poem, as we try to decipher words, lay bare their meaning and flesh them out with our own interpretations. It is a process of mining the riches offered by the poem. Expanding on this idea, Russo holds:

Rightly to understand this language, one often needs to seek out its origins on 
biographical, social, and historical grounds, for that is what gave birth to it. So understood, literary language connects us to the past-personal, communal, and historical. (Russo, 2005: 35)

Certainly, though, the artistic quality of the work together with the ensuing aesthetic experience itgenerates should never be overlooked.

Writing poetry is therapeutic, as is writing in general. When it comes to Plath, she asserts, in one of her journal entries: "Writing is my health" (Plath, 1959:523). In the case of Plath, again, such poetic medical therapy is preceded by a medicinalendeavorundertaken by the poetherself, as she becomesa surgeon,piercing the page of the poem that bleeds ink until it finallyreaches its finished version, that is, the poem that we have in print. Looking at Plath's different manuscripts, we find poems bleeding in draft after draft, as it were, before reaching its final shape.

Plath once wrote to her mother: "What a poet I will flay myself into" (Plath, 1958:381) — a statement that shows her aspirations to become a renown poet, part and parcel of the canon that she always wanted to emulate, poets such as "Eliot, Yeats, even Auden and Ransom" (Plath, 1959: 368). Her statement is equally telling if we comb through its ideological implications. Put differently, by flaying herself into a canonical poet, Plath sets on abrading the skin of the page as equipoise to her body, the female body, being dissected by the ideological machinery of the period, notably within the institution of the hospital.

Given the above observations, there are probably no better poems by Plath that illustrate the interplay between science, medicine and poetic expression than her so-called hospital poems. Among these poems, we can mention "Face Lift," "Tulips," and "In Plaster." In these poems, the speaker is a powerless patient whose body is literally dissected, peeled, tattooed over by male doctors, surgeons and anesthetists, and culturally manipulated by the well-oiled ideological apparatus of the fifties and early sixties. In yet another poem, entitled "The Surgeon at 2 A.M.," Plath's speaker seems to take over, appropriating the role of the surgeon, striving to heal her poems from all ailments ${ }^{3} .{ }^{3}$ What is more, she sets on pumping new blood into her poems, resuscitating those that are born dead-poems that "do not live," as she writes in "Stillborn" (Plath, 1960: 142). Symbolically, science, in this case, is placed at the service of poetry so as to 
reinvigorating it.

Another poem that traces the interplay between science and poetry is "Three Women: A Poem for Three Voices" which chimes in with the spirit of Narrative Medicine that I mentioned previously. "Three Women" is a dramatic, obstetrical poem, set in a maternity ward where three women exchange their experiences of pregnancy and childbirth. What is intriguing in this poem is neither the scientific nor the medicinal foci of childbirth, but actually the inherent ideological overtones. That is, ripping the veil off their traumatic experiences, both prior and after delivery, these three women actually disclose, bitterly but boldly, sexist and patriarchal practices.

Simone de Beauvoir describes pregnancy as "drama playing itself out in the woman between her and herself” (S. de Beauvoir, 2011: 539). In "Three Women," Plath adds other actors, mainly male, who playan equally pivotal role on the stage of this maternity ward. In this poem, Plath's female speakers are regarded as mere objects of science manipulated by male doctors hankering after scientific knowledge and heedless of their patients' pain. In this regard, mothering and birthing are presented as natural processes that can be approached and explained scientifically. Most importantly,Plath seems to stress the fact that they are also fraught with social, cultural, and even political implications. Similarly, Linda Lussy Fraser holds that these women try "to survive the ideological matrix of the maternity ward," for they are aware of the "commodification of [their bodies] into a site of (re)production,"transfixed by a glaring "clinical gaze"4 (Fraser, 1999: 548).

Indeed, “Three Women"stresses the deft interplay between science and poetry, and most importantly, between poetry and ideological realities of post-war America. It therefore provides the reader with "a poetic phenomenology of patienthood," as Christina Britzolakis rightly observes, hence the enticing fusion between medicine and art (Britzolakis, 1999: 92).

\section{Conclusion}

In a compelling remark about the discussion over the Humanities, Paul Jay rightly points out that "contemporary debates about the practical value of the humanities seem nearly as old as the humanities themselves" (Jay, 2014: 8).

Paul Dirac, one of the key theorists of quantum mechanics of the $20^{\text {th }}$ 
HSS, vol. VI, no. 2 (2017): 103-115

Century, revealed, quite bluntly, his bafflement over his fellow physicist Robert Oppenheimer's interest in poetry: "How can you do physics and poetry at the same time? The aim of science is to make difficult things understandable in a simpler way; the aim of poetry is to state simple things in an incomprehensible way. The two are incompatible" (258).

Whereas Dirac seems to disparage poetry, John Keats firmly argues in its favor, accusing science, which he calls "cold philosophy," of killing beauty and stifling the imagination, as he wonders:

Do not all charms fly

At the mere touch of cold philosophy?

Philosophy will clip an Angel's wings,

Conquer all mysteries by rule and line,

Empty the haunted air, and gnomed mine-

Unweave a rainbow... (Lamia 547)

Notwithstanding Dirac's and Keats's adverse opinions on poetry and science, William Wordsworth maintains that poetry remains "the first and last of all knowledge"through which a poet stands at the side of the "Man of science," "carrying sensation into the midst of the objects of the science itself' (qtd. in Helge, 1990: 11). It is true that poetic and scientific quests may require different energies, but the synergies they generate are just wondrous.

\section{References}

"Help Us Nip Efforts to Defund NEH in the Bud." 19 January 2017. http:/ /www.nhalliance.org/ Accessed 21 January 2017.

Aldama Luis, F. (2008).Why the Humanities Matter? A Commonsense Approach. Austin: U of Texas P.

Britzolakis, Ch. (1999).Sylvia Plath and the Theatre of Mourning. NY: Oxford UP.

De Beauvoir, S. (2011).The Second Sex.Trans. Constance Borde and Sheila Malovany-Chevallier. New York: Vintage.

Ellul, J. The Humiliation of the Word. Michigan: William B. Eerdmans Publishing Co., 1985.

Fraser, Linda Lussy. (1999). “Technologies of Reproduction: The Maternity Ward 
HSS, vol. VI, no. 2 (2017): 103-115

in Sylvia Plath's Three Women and Ingmar Bergman's Brink of Life." Women's Studies. Vol. 28: 547-574.

Helge, S.K. (1990).Dirac: A Scientific Biography.Cambridge: Cambridge UP,258.

Jay, P. (2014).The Humanities "Crisis" and the Future of Literary Studies. New York: Palgrave Macmillan.

Keats, J. (2001). "Lamia." Complete Poems and Selected Letters of John Keats. New York: The Modern Library.

Moore, M. (1981).The Complete Poems of Marianne Moore. New York: Penguin Group.

Nussbaum, C.M. (2010).Not for Profit: Why Democracy Needs the Humanities. Princeton and Oxford: Princeton UP.

Padel, R. "The Science of Poetry, the Poetry of Science." The Guardian.9 December 2011.https://www.theguardian.com/books/2011/dec/09/ruthpadel-science-poetry.Accessed November 2016.

Plath, S.The Collected Poems. New York: Harper, 1960.

Plath, S. (2000).The Unabridged Journals of Sylvia Plath, 1950-1962. Ed. K.V. Kukil. New York: Anchor Books.

Russo, J.P. (2005).The Future without a Past: The Humanities in a Technological Society. Columbia: U of Missouri P.

Stevens, W. (1960).The Necessary Angel: Essays on Reality and the Imagination. London: Faber.

Wordsworth, W. (1967).Lyrical Ballads.Eds. S. T. Coleridge and W. J. B. Owen. London: Oxford UP.

${ }^{1}$ This is a phrase that Nussbaum borrows from Rabindranath Tagore - an Indian poet and professor, winner of the Nobel Prize for Literature in 1913. Tagore created an interdisciplinary university that he called Visva-Bharati, which literally means "All-the-World." Tagore believes that students need to be exposed to Socratic argument practices, to world cultures, and to a different array of arts such as music, painting, theater, and dance as part and parcel of their curriculum.

2 These fields prepare students of the Humanities for academic and nonacademic jobs (given the shrinking teaching opportunities nowadays). Jay states that they are referred to as '“Alt-ac,' alternative careers to those in academia" (150). For a broader idea on these domains, Paul Jay's The Humanities "Crisis" and the Future of Literary Studies can be a good starting point.

${ }^{3}$ In the course of her artistic journey, Plath strove, at a time period fraught with containment at all levels, to overcome all sorts of impediments to her 
HSS, vol. VI, no. 2 (2017): 103-115

success as a woman writer, but above all, to divest her poems of the rigid formalism that characterized especially her early verse.

${ }^{4}$ For a comprehensive account of "the clinical gaze," consult Michel Foucault's seminal book The Birth of the Clinic.

\section{Biographical note}

Ikram Hili is a teaching assistant at the Higher Institute of Applied Languages of Moknine, Monastir (Tunisia). She earned a $\mathrm{PhD}$ degree from the Faculty of Letters, Arts, and Humanities of Manouba, Tunis, on the poetry of Sylvia Plath. She is a former Fulbright Visiting Scholar to Indiana University Bloomington and to Smith College in Massachusetts, USA, where she worked closely with Plath's archival materials. Her fields of interest are essentially $20^{\text {th }}$ Century American Poetry and Modern Manuscript Studies. 